\title{
GLP2: an underestimated signal for improving glycaemic control and insulin sensitivity
}

\author{
Antonella Amato, Sara Baldassano and Flavia Mulè \\ Dipartimento di Scienze e Tecnologie Biologiche Chimiche e Farmaceutiche (STEBICEF), \\ Università di Palermo, Palermo, Italy
}

Correspondence should be addressed to F Mulè

Email

flavia.mule@unipa.it

\begin{abstract}
Glucagon-like peptide 2 (GLP2) is a proglucagon-derived peptide produced by intestinal

enteroendocrine L-cells and by a discrete population of neurons in the brainstem, which projects mainly to the hypothalamus. The main biological actions of GLP2 are related to the regulation of energy absorption and maintenance of mucosal morphology, function and integrity of the intestine; however, recent experimental data suggest that GLP2 exerts beneficial effects on glucose metabolism, especially in conditions related to increased uptake of energy, such as obesity, at least in the animal model. Indeed, mice lacking GLP2 receptor selectively in hypothalamic neurons that express proopiomelanocortin show impaired postprandial glucose tolerance and hepatic insulin resistance (by increased gluconeogenesis). Moreover, GLP2 acts as a beneficial factor for glucose metabolism in mice with high-fat diet-induced obesity. Thus, the aim of this review is to update and summarize current knowledge about the role of GLP2 in the control of glucose homeostasis and to discuss how this molecule could exert protective effects against the onset of related obesity type 2 diabetes.
\end{abstract}

Key Words

- GLP2
Journal of Endocrinology (2016) 229, R57-R66

\section{Introduction}

Glucagon-like peptide 2 (GLP2) is a 33 amino acid proglucagon-derived peptide produced by a subset of enteroendocrine cells (L-cells) residing within the epithelium of the small and large intestine (Yusta et al. 2000). GLP2 is also produced in a discrete population of neurons in the brainstem, which projects mainly to the hypothalamus, brain area that plays a key role in control of food intake (Vrang et al. 2007). Prohormone convertase $1 / 3(\mathrm{PC} 1 / 3)$ processes proglucagon in the gastrointestinal tract and in the brain, resulting in glucagon-like peptide-1 (GLP1), GLP2, intervening peptide-2, oxynthomodulin and glicentin (Ugleholdt et al. 2004). The studies on proglucagon-derived peptides have supplied two classes of glucose-lowering agents, the dipeptidyl peptidase
IV (DPP-IV) inhibitors and GLP1 receptor agonists, useful tools for the treatment of type 2 diabetes (T2D) (Drucker \& Nauck 2006). However, the overwhelming interest attracted by GLP1 analogues as potent incretins has somewhat clouded the efforts to understand the importance of other proglucagon-derived peptides. In fact, unlike GLP1, initially, GLP2 was not reported to modulate insulin secretion or glucose homeostasis (Schmidt et al. 1985, Ørskov et al. 1988); however, recent experimental data suggest that GLP2 exerts beneficial effects on glucose metabolism, especially in conditions related to increased uptake of energy, such as obesity, at least in the animal model (Cani et al. 2009, Bahrami et al. 2010, Shi et al. 2013, Guan 2014, Baldassano et al. 2015).

Published by Bioscientifica Ltd 
Thus, the aim of this review is to update and summarize current knowledge about the role of GLP2 in the control of glucose homeostasis and to discuss how this molecule could exert protective effects against the onset of related obesity type 2 diabetes.

\section{Overview on GLP2}

GLP2 was first discovered as an intestinotrophic factor in 1996 (Drucker et al. 1996); however, today it is considered a pleiotropic hormone with a wide range of effects, mainly in the gastrointestinal tract. The main biological actions of GLP2 are related to the regulation of energy absorption and maintenance of mucosal morphology, function and integrity of the intestine (Drucker \& Yusta 2014 for an extensive review).

GLP2 is released in response to stimulation by luminal nutrients, such as glucose, fatty acids and dietary fibre (Brubaker 2006). GLP2 is cleaved to inactive GLP2 (3-33) by DPP-IV; consequently, the halflife of intravenous GLP2 is very short, about $7 \mathrm{~min}$ in healthy humans (Hartmann et al. 2000). Indeed, GLP2 (3-33) may act as a weak agonist at pharmacological concentrations (Shin et al. 2005); however, it is able to act as a competitive antagonist of the GLP2 receptor (GLP2R) in rodents (Thulesen et al. 2002, Shin et al. 2005, Baldassano et al. 2009, 2013). Then DPP-IV-resistant GLP2 analogues, such as [Gly²]-GLP2 (teduglutide), exhibit greater bioactivity relative to native molecule, due to their longer circulating half-lives (Tavares et al. 2000, Baldassano \& Amato 2014).

GLP2 promotes energy absorption within the gastrointestinal tract through non-specific and specific adaptation. In fact, it induces crypt cell proliferation and inhibition of apoptosis, resulting in an increase of villous height and in the expansion of the absorptive mucosal surface in the small and large intestine (Drucker et al. 1996, Tsai et al. 1997, Drucker \& Yusta 2014). Moreover, GLP2 increases the uptake of sugars by augmenting the activity and the expression of transporters (Cheeseman 1997, Au et al. 2002, Ramsanahie et al. 2004, Sueyoshi et al. 2014) and by enhancing the expression of different enzymes involved in digestion (Brubaker et al. 1997a, Petersen et al. 2002). Evidence from studies on humans and animal models suggests that GLP2 also plays a role in lipid absorption. Indeed, GLP2 facilitates intestinal absorption of lipids (Meier et al. 2006, Hsieh et al. 2009) and enhances and regulates chylomicron secretion from the intestine (Hsieh et al. 2009, Hein et al. 2013, Dash et al. 2014).
The gastrointestinal responses to GLP2 are mediated via GLP2R, a member of the glucagon/secretin G proteincoupled receptor superfamily that is located on enteric (Bjerknes \& Cheng 2001, Baldassano et al. 2009) and vagal nerves (Nelson et al. 2007), subepithelial myofibroblasts (Ørskov et al. 2005) and a subset of intestinal epithelial cells (Thulesen et al. 2000). Activation of GLP2 receptors regulates epithelial cell growth (Tsai et al. 1997, Bjerknes \& Cheng 2001), reduces intestinal permeability, enhances the barrier function (Benjamin et al. 2000, Moran et al. 2012, Drucker \& Yusta 2014), increases mesenteric blood flow (Guan et al. 2006, Stephens et al. 2006, Bremholm et al. 2009) and inhibits gastrointestinal motility, thus providing another mechanism to increase digestion and absorption of nutrient (Wøjdemann et al. 1998, McDonagh et al. 2007, Amato et al. 2009, 2010, Cinci et al. 2011).

GLP2R is also expressed in the central nervous system (CNS), specifically in key regions of the brain for energy balance, including the hypothalamus, hippocampus and brainstem (Tang-Christensen et al. 2000, Lovshin et al. 2004, Guan et al. 2012). As a neurotransmitter, GLP2 may mediate preproglucagonergic (PPG) neuron-induced synaptic transmission linking the hypothalamus and the brainstem and may act as a satiation signal in the control of feeding behaviour (Tang-Christensen et al. 2000). In fact, intracerebroventricular administrations of GLP2 reduce food intake in rodents (Tang-Christensen et al. 2000, Lovshin et al. 2001). In addition, knockout mice with GLP2R deletion selectively in hypothalamic arcuate nucleus neurons expressing proopiomelanocortin (POMC) display hyperphagic behaviour and late-onset obesity (Guan et al. 2012). These observations support the hypothesis of a physiological role in the regulation of food intake and body weight (Guan et al. 2012). Up to date, studies in humans have not demonstrated a decrease in food intake after peripheral GLP2 administration (Schmidt et al. 2000, Sørensen et al. 2003), even if recent data have shown that intraperitoneal injections of GLP2 or $\left[\mathrm{Gly}^{2}\right]-\mathrm{GLP} 2$ reduce food intake in mice, suggesting a role for GLP2 in the short-term regulation of the eating behaviour (Baldassano et al. 2012). This effect is related to a significant decrease in the rate of gastric emptying (Baldassano et al. 2012), and it is well known that gastric emptying is a critical process for the short-term control of food intake (Janssen et al. 2011, Rotondo et al. 2011a). Moreover, in mice, GLP2R deletion in POMC neurons accelerates the rate of gastric emptying accounting for the hyperphagic behaviour and supporting the hypothesis that CNS GLP2 is a key satiety signal for the physiological short-term control of feeding behaviour (Guan et al. 2012).

Published by Bioscientifica Ltd 


\section{GLP2 and glycaemic control}

Up to date, the GLP2 action on glucose homeostasis has been scarcely investigated, and the importance of GLP2R signalling is not clear yet (Guan 2014). GLP2R global deficiency is not critical for glucose homeostasis in normal or lean diabetic mice because it is not associated with changes in fasting glucose, glucose tolerance or plasma glucagon level (Bahrami et al. 2010). Also the observation that the chronic treatment with GLP2 (3-33), a GLP2R antagonist used to reveal the physiological actions of GLP2 (Shin et al. 2005, Nelson et al. 2008, Iakoubov et al . 2009, Baldassano et al. 2013), does not affect glycaemic parameters, glucose tolerance, insulin sensitivity or pancreas weight and $\beta$-cell mass in mice, has led to rule out a role for the endogenous GLP2 in glucose homeostasis in normal conditions (Baldassano et al. 2015). In addition, changes in glucagon levels or glycaemia have not been reported following acute or chronic GLP2 or teduglutide administration in patients with short bowel syndrome (Drucker \& Yusta 2014).

We know for a long time that GLP2 does not exhibit any insulin-releasing properties (Schmidt et al. 1985, Ørskov et al. 1988). On the contrary, i.v. infusion of the peptide has been demonstrated to increase glucagon secretion in healthy, non-obese human subjects both in physiological and pharmacological plasma concentration (Sørensen et al. 2003, Meier et al. 2006) or in diabetic patients (Christensen et al. 2010, Lund et al. 2011). GLP2R has been localized to $\alpha$-cells in both human and rat islets by means of immunohistochemistry as well as real-time PCR (de Heer et al. 2007). In contrast, full-length Glp2r mRNA transcripts have not been detected in RNA from murine islets, and GLP2 does not increase plasma glucagon levels in mice (Yusta et al. 2000, Bahrami et al. 2010). The discrepancy could be attributed to different species; however, caution should be taken in ruling out a glucagonotrophic role of GLP2 in mice. In fact, recent researches have demonstrated that GLP2R is more widely expressed than it was estimated (Angelone et al. 2012, El-Jamal et al. 2014). Therefore, it is necessary to explore the presence and localization of GLP2R in the pancreatic islets using validated GLP2R antibody and the opportune positive and negative controls to yield to conclusive results. Anyway, the GLP2 glucagonotrophic properties could suggest that the endogenous or exogenous peptide exacerbates the hyperglycaemia conditions related to diabetes. Nevertheless, the glucagon hypersecretion induced by oral glucose, which is typical of patients with T2D (Knop et al. 2007), is not a consequence of exaggerated secretion or effect of GLP2 (Lund et al. 2011), and GLP2R global absence in genetically obese mice increases glucagon secretion and hyperglycaemia (Bahrami et al. 2010). Therefore, the importance of GLP2 in the control of glucagon secretion in different species and in diverse pathological conditions related to glucose impairment requires further elucidation.

New evidence obtained from GLP2R tissue-specific $\mathrm{KO}$ mice indicates that GLP2R in POMC neurons is essential for suppressing hepatic glucose production (Shi et al. 2013). Indeed, mice lacking GLP2R selectively in POMC neurons display impaired postprandial glucose tolerance and hepatic insulin resistance (by increased gluconeogenesis), suggesting a physiological significance of GLP2 neural action in glycaemic control. Moreover, intracerebroventricular infusion of GLP2 increases glucose tolerance and insulin sensitivity and suppresses basal hepatic glucose production through GLP2R activation in POMC neurons (Shi et al. 2013). Therefore, GLP2 has been proposed as a crucial neuroendocrine signal for glucose homeostasis (Guan 2014). It will be crucial to determine whether CNS GLP2R is a key contributor to glycaemic control and insulin sensitivity also in humans.

Moreover, GLP2 seems to act as a beneficial factor for glucose metabolism in obesity condition. Loss of GLP2R leads to increased glucagon secretion and $\alpha$-cell mass, impaired intraperitoneal glucose tolerance and hyperglycaemia, reduced $\beta$-cell mass and decreased islet proliferation in genetic obese ob/ob:Glp2 $r^{-1-}$ mice. Then, the authors have suggested that GLP2R is required for the adaptation of the endocrine pancreas to metabolic stress (Bahrami et al. 2010). In mice fed a high-fat diet (HFD), endogenous GLP2 acts as a protective factor against the dysregulation of glucose metabolism that occurs in HFD-fed mice because GLP2 (3-33) chronic treatment exacerbates glucose metabolism disorders (Baldassano et al. 2015). It is well known that in C57BL/6J mouse model, a chronic exposure to HFD induces obesity and a progressive deterioration of metabolic control, characterized by hyperglycaemia, hyperinsulinaemia and peripheral and central insulin resistance (Surwit et al. 1988, Ahrén et al. 1997, Lee et al. 1995, Nuzzo et al. 2015). Mice after 10 weeks on HFD have greater mass gain compared with standard diet-fed mice, show hyperglycaemia, an impaired glycaemic response following intraperitoneal glucose load, high plasma insulin level after glucose load, increased pancreas weight and $\beta$ cell expansion, but not insulin resistance. In HFD-fed mice, GLP2 (3-33) treatment for 4 weeks (from the sixth to the tenth week of diet) does not affect fasting

Published by Bioscientifica Ltd. 
glycaemia; however, it significantly increases glucose intolerance, enhances both fasting and glucose-induced insulin concentrations and reduces sensitivity to insulin. Therefore, the reduction of GLP2R signalling accelerates the process leading to insulin resistance in HFD-fed mice (Baldassano et al. 2015). On the contrary, long-term exposure to GLP2 stable analogue improves the obesityrelated glucose dysmetabolism in a concentrationdependent manner (Baldassano et al. 2016a). In fact, HFD-fed mice treated with pharmacological doses of Gly²-GLP2 for 4 weeks show a significant increase in glucose tolerance and exogenous insulin sensitivity and reduction in glucose-stimulated plasma insulin levels in comparison with pair-aged HFD-untreated animals, suggesting that the peptide is able to delay the onset of insulin resistance (Baldassano et al. 2016a). Indeed, a previous study has described the failure of GLP2 to modify diabetes onset in non-obese diabetic mouse, a model of type 1 diabetes (T1D) (Hadjiyanni et al. 2009). Therefore, due to different aetiology of T1D compared with T2D, it could be proposed that the protective role is associated exclusively with obesity conditions. An association between insulin resistance and GLP2 secretion has been found in a pilot study on obese human subjects (Geloneze et al. 2013). Hypothesis has been advanced that GLP2-increased secretion could be the cause of insulin resistance as GLP2 increases absorption of nutrients, especially fatty acids, a key factor for insulin resistance (Delarue \& Magnan 2007) or for its glucagonotrophic action in healthy or diabetic subjects (Christensen et al. 2010, Lund et al. 2011). Glucagon is counter-regulatory to insulin action, increasing glucose output and inhibiting glucose uptake in the liver, and it has been linked to insulin resistance in obese subjects with normal or impaired glucose tolerance (Ahrén 2006, Weiss et al. 2011). However, this appears unlikely because bariatric surgery, particularly Roux-en-Y gastric bypass (RYGB) (Saeidi et al. 2013), which is the most effective therapy for obesity and T2D (Carlsson et al. 2012, Cummings 2012), increases blood GLP2 (by 200\%) at postprandial status (le Roux et al. 2010). Bariatric surgery normalizes blood glucose concentrations in the majority of T2D humans independent of weight loss (Mingrone et al. 2012, Schauer et al. 2012) and can induce diabetes remission up to 6 years (Cohen et al. 2012). It is likely that the enhancement of nutrient flux into the distal small intestine after bariatric surgery triggers a signal leading to an antidiabetic effect that does not appear related to gastric inhibitory peptide
(GIP) or GLP1 (Breen et al. 2013). In fact, changes in circulating GLP1 are not consistent between models of diabetes that received duodenal-jejunal bypass (Breen et al. 2012). Moreover, bariatric surgery still improves glucose tolerance in GLP1 receptor-deficient HFD-fed mice (Wilson-Pérez et al. 2013). Therefore, GLP2 could be responsible for glycaemic improvement after bariatric surgery and can be considered as a key signal to drive intestinal reprogramming of glucose metabolism (Saeidi et al. 2013). In addition, animal studies have shown that GLP2 secretion from ileal tissue is decreased in diabetic conditions (Shan et al. 2013), and reduced numbers of L-cells have been detected in the intestinal tissue from HFD-fed mice compared with intestinal tissue from mice receiving a control diet (Kappe et al. 2014). Therefore, GLP2-decreased production might lead to T2D. Further studies are needed to clarify definitively whether and how GLP2 is involved in the improvement of glycaemic control after bariatric surgery.

We speculate that GLP2 may act as a protective factor against the deregulation of the glucose metabolism that occurs in obese conditions. Of note, in obese patients without T2D, GLP2 concentrations in plasma are higher $(8500 \mathrm{pg} / \mathrm{mL})$ (Valderas et al. 2014) than in healthy human subjects $(851 \pm 230 \mathrm{pg} / \mathrm{mL}$ ) (Brubaker et al. 1997b). These GLP2 plasma high levels can be interpreted as a beneficial factor against T2D development. Also HFD-fed obese mice show GLP2 plasma levels higher than those in lean animals (Baldassano et al. 2013) and increased gut gene and protein expression of GLP2R (Rotondo et al. 2011b, Baldassano et al. 2013). Although nothing is known about the expression in human individuals, the positive correlation between GLP2 plasma levels and GLP2R mRNA and protein abundance indicates that Glp2r expression is not negatively affected by increased plasma GLP2 concentrations and could be interpreted as an adaptive signal involved in the regulation of glucose metabolism in conditions of obesity. In fact, as endogenous GLP2 causes a trophic effect on the mucosa of the small intestine with increased absorptive surface in HFD-fed obese mice (Baldassano et al. 2013), the hormone could aim to preserve and improve the glucose metabolic disorders induced by HFD. Although down-regulation after exposure to the receptor ligand is a common phenomenon, diverse studies report that exogenous GLP2 or inhibition of DDPIV (which doubles GLP2 levels) augments GLP2R expression in ileum and jejunum (Koopmann et al. 2008, Sueyoshi et al. 2014).
(C) 2016 Society for Endocrinology Printed in Great Britain
Published by Bioscientifica Ltd. 


\section{Mechanistic insight}

The mechanisms underlying the beneficial effect of GLP2 on glucose metabolism remain to be established.

About glucose homeostasis in healthy mice, an elegant, recent work has pointed out that GLP2 can surely act in the CNS. In fact, GLP2 is able to modulate the excitability of POMC neurons in GLP2R- and PI3Kdependent manner (Shi et al. 2013). Hypothesis has been advanced that GLP2 activates POMC neurons to release $\alpha$-melanocyte-stimulating hormone. This hormone activates melanocortin receptor 4-positive cholinergic neurons of vagal dorsal motor nucleus that enhance hepatic vagal output to suppress hepatic glucose production (Guan 2014). Alternatively, GLP2 may activate neurons in the nucleus of the solitary tract via afferent vagal inputs to modulate glucose metabolism. In fact, GLP2 activates vagal afferent pathways where GLP2R is expressed (Nelson et al. 2007). Although GLP2-modulated neural circuitries have not been fully defined, it has been speculated that GLP2R activation on vagal afferents may influence the preproglucagonergic neurons in the brainstem nucleus of solitary tract with consequent release of GLP2-activating hypothalamic neurons and vagal outputs from dorsal motor nucleus to regulate control of feeding behaviour and glucose homeostasis (Guan 2014). Anyway, according to these hypotheses, the glycaemic control by GLP2 involves fine-tuning vagal outputs. One problem is represented by the identification of the GLP2 source (endocrine L-cells or PPG neurons), responsible for the control of glucose metabolism. Of note, to date, to our knowledge, there is no report on the passage of GLP2 across the blood-brain barrier (BBB); however, peripheral hormone could act in the hypothalamic arcuate nucleus where BBB is semipermeable.

The molecular mechanisms and the tissue targets underlying the beneficial effect of GLP2 on glucose metabolism in obese/HFD-fed mice have not been established yet (Baldassano et al. 2015, 2016a), but different speculations may be made (Fig. 1).

Because no changes in body weight or in the daily food intake have been observed in GLP2 (3-33)- or Gly2-GLP2-treated mice in comparison with untreated animals, an indirect effect mediated by an anti-obesity action has been ruled out (Baldassano et al. 2015, 2016a). It is well known that reduced adiposity could contribute to the preservation of insulin sensitivity because the adipose tissue has a considerable influence on systemic glucose homeostasis through secretion of adipocytokines (McArdle et al. 2013). Interestingly, Glp2r mRNA expression has been detected in mouse mesenteric adipose tissue (El-Jamal et al. 2014); however, its functional significance is still unknown. It is important to characterize whether GLP2 increases glucose incorporation in adipocytes when their response to insulin is impaired by obesity conditions. In fact, although there are conflicting reports regarding the alterations in the basal glucose uptake, most reports provide evidence that insulin-induced glucose incorporation is suppressed in the obese state (Talior et al. 2003, Sancho et al. 2006, Crowe et al. 2008), and as GLP2

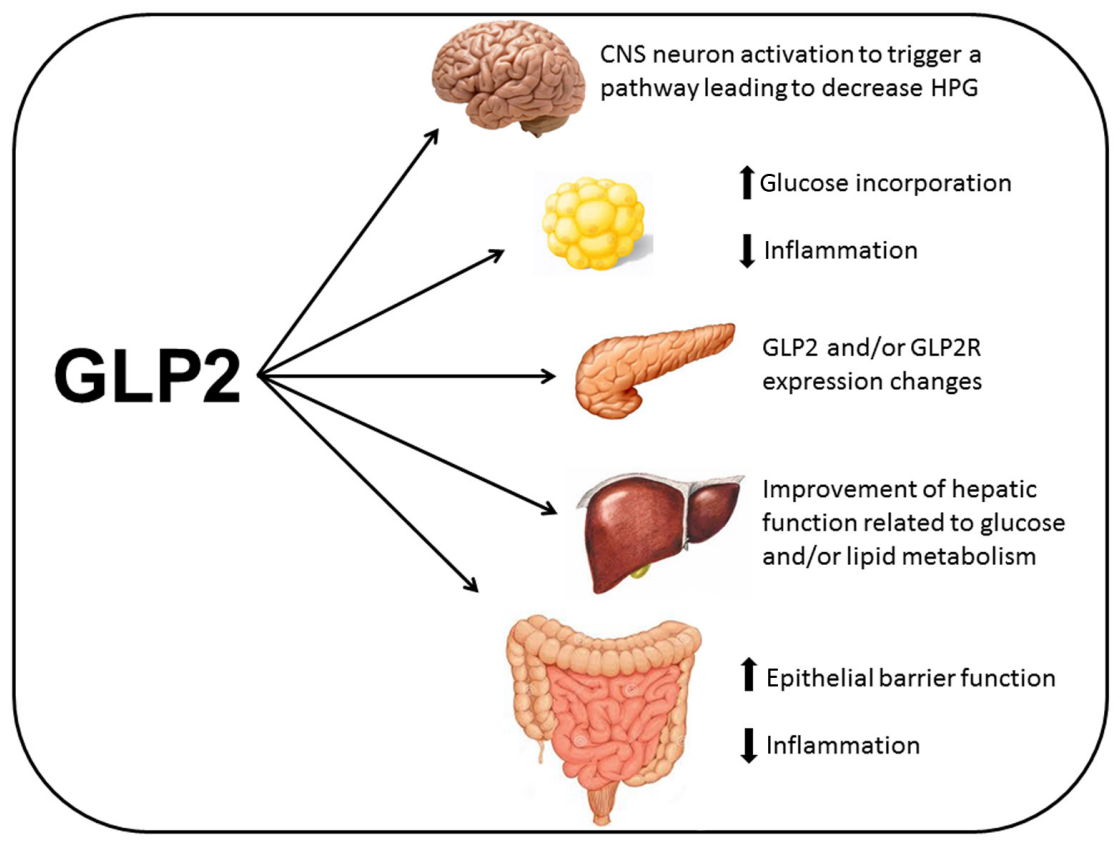

Figure 1

Hypothetical targets and relative actions responsible for the beneficial effects of GLP2 on glucose dysmetabolism in HFD-fed obese mice. A full colour version of this figure is available at http://dx.doi.org/10.1530/JOE-16-0035. 
rapidly increases intestinal hexose absorption (Cheeseman 1997, Au et al. 2002), it is not unlikely to hypothesize that it contributes to clearance of plasma glucose through an action on adipocytes. In addition or alternatively, GLP2 might influence and modulate the quality and quantity of secreted adipokines and the inflammatory state of adipose tissue.

Another hypothetical target for GLP2 could be represented by pancreas. Indeed, a direct action on $\beta$-cell function is improbable because the Glp2r mRNA transcripts have not been detected in pancreatic islets, but only in mouse whole pancreas (Bahrami et al. 2010) or rat and human pancreatic $\alpha$-cells (de Heer et al. 2007). Despite exogenous GLP2 increases glucagon secretion (Meier et al. 2006, de Heer et al. 2007), elimination of GLP2R signalling in genetically obese mice leads to increased glucagon secretion and $\alpha$-cell mass, which has been interpreted as due to increased proinflammatory signals (Bahrami et al. 2010), for example interleukin-6, in turn, involved in $\alpha$-cell mass expansion (Ellingsgaard et al. 2008). Unluckily, glucagon levels were not measured in HFD-fed mice after GLP2 (3-33) or Gly²-GLP2 chronic treatment. Of note, GLP2 and GLP2R expression might change following HFD, as reported in gut tissue (Rotondo et al. 2011b, Baldassano et al. 2013). Moreover, recent studies on glucose-dependent insulinotrophic polypeptide (GIP) and GLP1 have pointed out that both hormones are synthesized and secreted from islet $\alpha$-cells under conditions of cellular stress imposed by $\beta$ cytotoxic attack or increased insulin demand (Fujita et al. 2010, Donath \& Burcekin 2013, Moffett et al. 2014). Increased expression of PC1/3 relative to PC 2 in islet $\alpha$-cells directs proglucagon processing away from glucagon towards GLP1 in these conditions (Wideman et al. 2007, Marchetti et al. 2012). As GLP1 and GLP2 are produced by the same convertase in equimolar amount (Janssen et al. 2013), it is likely to hypothesize that GLP2 pancreatic expression also changes in stress conditions, such as derangements of islet cell function associated with prolonged consumption of HFD. Therefore, before reaching any conclusions about a link between GLP2 and pancreas function, it is necessary to verify whether GLP2 and GLP2R expressions in pancreatic islets also change consistently with their beneficial role in glucose metabolism.

It is also possible that GLP2 acts directly on the liver to modulate hepatic function related to glucose or lipid metabolism. Mouse liver expresses GLP2R (El-Jamal et al. 2014); however, nothing is known about other species, including humans. Moreover, fatty liver is strongly associated with insulin resistance (Asrih \&
Jornayvaz 2013), and non-alcoholic hepatic steatosis has been reported in HFD-fed mice (de Meijer et al. 2010, Fraulob et al. 2010). Indeed, in HFD-fed mice, chronic treatment with GLP2 (3-33) aggravates dyslipidaemia and hepatic lipid accumulation. It increases plasma triglyceride, cholesterol, ALT and AST levels, intrahepatic lipid concentration, reduces HDL and exacerbates the liver steatosis, suggesting that endogenous GLP2 may exert defensive role against lipid imbalance in obesity condition (Baldassano et al. 2016b). However, chronic administration of Gly²-GLP2 for 4 weeks is not associated with remarkable improvements in dyslipidaemia-related circulating parameters, and it does not prevent liver fat accumulation and the presence of microvesicular steatosis, suggesting that the level of insulin sensitivity in peptide-treated mice is not related to an apparently less severe tissue fat infiltration. Therefore, the beneficial effects of GLP2 chronic treatment on insulin sensitivity do not seem to be a consequence of an improvement in lipid metabolism (Baldassano et al. 2016a).

Another potential account for explaining endogenous or exogenous GLP2-protective effects against insulin resistance is related to GLP2 ability to reduce gut permeability and consequently the leakage of bacterial endotoxins into the portal blood circulation (Benjamin et al. 2000). Endotoxemia and low-grade inflammation have been associated with insulin resistance (Hotamisligil 2006, Cani et al. 2007), and activation of inflammatory pathways has emerged as an imperative link between T2D and obesity (Hameed et al. 2015). It is well accepted that GLP2 is involved in modulation of intestinal permeability (Moran et al. 2012). In diabetic rats, plasma lipopolysaccharide, zonulin 1 expression, insulin level and insulin-resistant index are closely related to GLP2 levels (Shan et al. 2013). On the basis of these observations, the authors advanced the very suggestive hypothesis that impaired GLP2 in prediabetic subjects may predispose these patients to T2D by increasing intestinal permeability and endotoxemia-related inflammation. However, prospective studies in humans are needed. They found that glutamine-induced GLP2 secretion is decreased in rats with streptozotocin-induced experimental diabetes (Shan et al. 2013). Impaired GLP1 secretion is a characteristic of the prediabetic situation such as impaired glucose tolerance and gestational diabetic mellitus (Lim \& Brubaker 2006) and likely also GLP2 secretion from the same L-cells is impaired. However, the fasting plasma GLP2 concentrations reported in humans with glucose dysmetabolism (Gjesing et al. 2011) or patients with T2D (Aaboe et al. 2010) are lesser than those in healthy human subjects (Brubaker

Published by Bioscientifica Ltd. 
et al. 1997b). Also obese mice exhibit an altered gut barrier (Brun et al. 2007), and increased endogenous production of GLP2 induced by prebiotic diet improves gut barrier function (Cani et al. 2009). In fact, the block of the GLP2R exacerbates inflammation, whereas therapy with GLP2 reduces systemic and hepatic inflammation in ob/ob mice (Cani et al. 2009). Therefore, it is conceivable that GLP2 by enhancing epithelial barrier function and limiting the activation of processes that drive inflammation (Moore et al. 2010) can delay and reduce the development of insulin resistance. However, this hypothesis needs to be verified.

\section{Conclusion and perspective}

New evidence underlines the importance of GLP2 in promoting the control and insulin sensitivity in animal model, particularly in conditions associated with obesity. Results from human studies so far remain inconsistent; therefore, future research should be addressed to clarify the role of GLP2 in preventing human insulin resistance and, in turn, the development of T2D. The potential mechanisms driving the beneficial effects of GLP2 receptor activation may be multiple and not fully elucidated. Greater attention should also be given to investigate on this hormone and its receptor as targets for treatment of obesity-associated diabetes in consideration of the chemical strategies for the design of multifunctional peptides.

\section{Declaration of interest}

The authors declare that there is no conflict of interest that could be perceived as prejudicing the impartiality of this review.

\section{Funding}

This work was supported by a grant from University of Palermo (FFR 2012).

\section{References}

Aaboe K, Knop FK, Vilsbøll T, Deacon CF, Holst JJ, Madsbad S \& Krarup T 2010 Twelve weeks treatment with the DPP-4 inhibitor, sitagliptin, prevents degradation of peptide YY and improves glucose and nonglucose induced insulin secretion in patients with type 2 diabetes mellitus. Diabetes Obesity and Metabolism 12 323-333. (doi:10.1111/ j.1463-1326.2009.01167.x)

Ahrén B 2006 Glucagon secretion in relation to insulin sensitivity in healthy subjects. Diabetologia 49 117-122. (doi:10.1007/s00125-0050056-8)

Ahrén B, Simonsson E, Scheurink AJ, Mulder H, Myrsen U \& Sundler F 1997 Dissociated insulinotropic sensitivity to glucose and carbachol in high-fat diet-induced insulin resistance in C57BL/6J mice. Metabolism 46 97-106. (doi:10.1016/S0026-0495(97)90175-X)

Amato A, Baldassano S, Serio R \& Mulè F 2009 Glucagon-like peptide-2 relaxes mouse stomach through vasoactive intestinal peptide release. American Journal of Physiology: Gastrointestinal and Liver Physiology 296 G678-G684. (doi:10.1152/ajpgi.90587.2008)

Amato A, Rotondo A, Cinci L, Baldassano S, Vannucchi MG \& Mulè F 2010 Role of cholinergic neurons in the motor effects of glucagonlike peptide- 2 in mouse colon. American Journal of Physiology: Gastrointestinal and Liver Physiology 299 G1038-G1044. (doi:10.1152/ ajpgi.00282.2010)

Angelone T, Filice E, Quintieri AM, Imbrogno S, Amodio N, Pasqua T, Pellegrino D, Mulè F \& Cerra MC 2012 Receptor identification and physiological characterization of glucagon-like peptide- 2 in the rat heart. Nutrition, Metabolism, and Cardiovascular Diseases 22 486-494. (doi:10.1016/j.numecd.2010.07.014)

Asrih M \& Jornayvaz FR 2013 Inflammation as a potential link between nonalcoholic fatty liver disease and insulin resistance. Journal of Endocrinology 218 R25-R36. (doi:10.1530/JOE-13-0201)

Au A, Gupta A, Schembri P \& Cheeseman CI 2002 Rapid insertion of GLUT2 into the rat jejunal brush-border membrane promoted by glucagon-like peptide 2. Biochemical Journal 367 247-254. (doi:10.1042/bj20020393)

Bahrami J, Longuet C, Baggio LL, Li K \& Drucker DJ 2010 The glucagonlike peptide- 2 receptor modulates islet adaptation to metabolic stress in the ob/ob mouse. Gastroenterology 139 857-868. (doi:10.1053/j. gastro.2010.05.006)

Baldassano S \& Amato A 2014 GLP-2: what do we know? What are we going to discover? Regulatory Peptides 194-195 6-10. (doi:10.1016/j. regpep.2014.09.002)

Baldassano S, Liu S, Qu MH, Mulè F \& Wood JD 2009 Glucagon-like peptide-2 modulates neurally evoked mucosal chloride secretion in guinea pig small intestine in vitro. American Journal of Physiology: Gastrointestinal and Liver Physiology 297 G800-G805. (doi:10.1152/ ajpgi.00170.2009)

Baldassano S, Bellanca AL, Serio R \& Mulè F 2012 Food intake in lean and obese mice after peripheral administration of glucagon-like peptide 2 . Journal of Endocrinology 213 277-284. (doi:10.1530/JOE-12-0092)

Baldassano S, Amato A, Cappello F, Rappa F \& Mulè F 2013 Glucagon-like peptide- 2 and mouse intestinal adaptation to a high-fat diet. Journal of Endocrinology 217 11-20. (doi:10.1530/JOE-12-0500)

Baldassano S, Rappa F, Amato A, Cappello F \& Mulè F 2015 GLP-2 as beneficial factor in the glucose homeostasis in mice fed a high fat diet. Journal of Cellular Physiology 230 3029-3036. (doi:10.1002/ jcp.25039)

Baldassano S, Amato A, Caldara GF \& Mulè F 2016 $a$ Glucagon-like peptide-2 treatment improves glucose dysmetabolism in mice fed a high fat diet. Endocrine [in press]. (doi:10.1007/s12020-016-0871-3)

Baldassano S, Amato A, Rappa F, Cappello F \& Mulè F $2016 b$ Influence of endogenous glucagon like peptide- 2 on lipid disorders in mice fed a high fat diet. Endocrine Research [in press]. (doi:10.3109/074358 $00.2016 .1141950)$

Benjamin MA, McKay DM, Yang PC, Cameron H \& Perdue MH 2000 Glucagon-like peptide-2 enhances intestinal epithelial barrier function of both transcellular and paracellular pathways in the mouse. Gut 47 112-119. (doi:10.1136/gut.47.1.112)

Bjerknes M \& Cheng H 2001 Modulation of specific intestinal epithelial progenitors by enteric neurons. PNAS 98 12497-12502. (doi:10.1073/ pnas.211278098)

Breen DM, Rasmussen BA, Kokorovic A, Wang R, Cheung GW \& Lam TK 2012 Jejunal nutrient sensing is required for duodenal-jejunal bypass surgery to rapidly lower glucose concentrations in uncontrolled diabetes. Nature Medicine 18 950-955. (doi:10.1038/nm.2745)

Breen DM, Rasmussen BA, Côté CD, Jackson VM \& Lam TK 2013 Nutrient-sensing mechanisms in the gut as therapeutic targets for diabetes. Diabetes 62 3005-3013. (doi:10.2337/db13-0523) 
Bremholm L, Hornum M, Henriksen BM, Larsen S \& Holst JJ 2009 Glucagon-like peptide-2 increases mesenteric blood flow in humans. Scandinavian Journal of Gastroenterology 44 314-319. (doi:10.1080/00365520802538195)

Brubaker PL 2006 The glucagon-like peptides: pleiotropic regulators of nutrient homeostasis. Annals of the New York Academy of Sciences 1070 10-26. (doi:10.1196/annals.1317.006)

Brubaker PL, Izzo A, Hill M \& Drucker DJ 1997a Intestinal function in mice with small bowel growth induced by glucagon-like peptide- 2 . American Journal of Physiology 272 E1050-E1058.

Brubaker PL, Crivici A, Izzo A, Ehrlich P, Tsai CH \& Drucker DJ $1997 b$ Circulating and tissue forms of the intestinal growth factor, glucagonlike peptide-2. Endocrinology 138 4837-4843.

Brun P, Castagliuolo I, Di Leo V, Buda A, Pinzani M, Palù G \& Martines D 2007 Increased intestinal permeability in obese mice: new evidence in the pathogenesis of nonalcoholic steatohepatitis. American Journal of Physiology. Gastrointestinal and Liver Physiology 292 G518-G525. (doi:10.1152/ajpgi.00024.2006)

Cani PD, Amar J, Iglesias MA, Poggi M, Knauf C, Bastelica D, Neyrinck AM, Fava F, Tuohy KM, Chabo C, et al. 2007 Metabolic endotoxemia initiates obesity and insulin resi stance. Diabetes $\mathbf{5 6}$ 1761-1772. (doi:10.2337/db06-1491)

Cani PD, Possemiers S, Van de Wiele T, Guiot Y, Everard A, Rottier O, Geurts L, Naslain D, Neyrinck A, Lambert DM, et al. 2009 Changes in gut microbiota control inflammation in obese mice through a mechanism involving GLP-2-driven improvement of gut permeability. Gut 58 1091-1103. (doi:10.1136/gut.2008.165886)

Carlsson LM, Peltonen M, Ahlin S, Anveden A, Bouchard C, Carlsson B, Jacobson P, Lonroth H, Maglio C, Naslund I, et al. 2012 Bariatric surgery and prevention of type 2 diabetes in Swedish obese subjects. New England Journal of Medicine 367 695-704. (doi:10.1056/ NEJMoa1112082)

Cheeseman CI 1997 Upregulation of SGLT-1 transport activity in rat jejunum induced by GLP-2 infusion in vivo. American Journal of Physiology 273 R1965-R1971.

Christensen M, Knop FK, Vilsbøll T, Aaboe K, Holst JJ, Madsbad S \& Krarup T 2010 Glucagon-like peptide-2, but not glucose-dependent insulinotropic polypeptide, stimulates glucagon release in patients with type 1 diabetes. Regulatory Peptides 163 96-101. (doi:10.1016/j. regpep.2010.05.004)

Cinci L, Faussone-Pellegrini MS, Rotondo A, Mulè F \& Vannucchi MG 2011 GLP-2 receptor expression in excitatory and inhibitory enteric neurons and its role in mouse duodenum contractility. Neurogastroenterology and Motility 23 e383-e392. (doi:10.1111/j.13652982.2011.01750.x)

Cohen RV, Pinheiro JC, Schiavon CA, Salles JE, Wajchenberg BL \& Cummings DE 2012 Effects of gastric bypass surgery in patients with type 2 diabetes and only mild obesity. Diabetes Care 35 1420-1428. (doi:10.2337/dc11-2289)

Crowe S, Turpin SM, Ke F, Kemp BE \& Watt MJ 2008 Metabolic remodeling in adipocytes promotes ciliary neurotrophic factormediated fat loss in obesity. Endocrinology 149 2546-2556. (doi:10.1210/en.2007-1447)

Cummings DE 2012 Metabolic surgery for type 2 diabetes. Nature Medicine 18 656-658. (doi:10.1038/nm.2773)

Dash S, Xiao C, Morgantini C, Connelly PW, Patterson WB \& Lewis GF 2014 Glucagon-like peptide 2 regulates release of chylomicron from the intestine. Gastroenterology 2 1-10. (doi:10.1053/j. gastro.2014.08.037)

de Heer J, Pedersen J, Ørskov C \& Holst JJ 2007 The alpha cell expresses glucagon-like peptide- 2 receptors and glucagon-like peptide- 2 stimulates glucagon secretion from the rat pancreas. Diabetologia 50 2135-2142. (doi:10.1007/s00125-007-0761-6)

de Meijer VE, Le HD, Meisel JA, Akhavan Sharif MR, Pan A, Nosé V \& Puder M 2010 Dietary fat intake promotes the development of hepatic steatosis independently from excess caloric consumption in a murine model. Metabolism 59 1092-1105. (doi:10.1016/j. metabol.2009.11.006)

Delarue J \& Magnan C 2007 Free fatty acids and insulin resistance. Current Opinion in Clinical Nutrition and Metabolic Care 10 142-148. (doi:10.1097/MCO.0b013e328042ba90)

Donath MY \& Burcelin R 2013 GLP-1 effects on islets: hormonal, neuronal, or paracrine? Diabetes Care 36 S145-S148. (doi:10.2337/ dcS13-2015)

Drucker DJ \& Nauck MA 2006 The incretin system: glucagon-like peptide- 1 receptor agonists and dipeptidyl peptidase- 4 inhibitors in type 2 diabetes. Lancet 368 1696-1705. (doi:10.1016/S01406736(06)69705-5)

Drucker DJ \& Yusta B 2014 Physiology and pharmacology of the enteroendocrine hormone glucagon-like peptide-2. Annual Review of Physiology 76 561-583. (doi:10.1146/annurevphysiol-021113-170317)

Drucker DJ, Erlich P, Asa SL \& Brubaker PL 1996 Induction of intestinal epithelial proliferation by glucagon-like peptide 2. PNAS 93 7911-7916. (doi:10.1073/pnas.93.15.7911)

El-Jamal N, Erdual E, Neunlist M, Koriche D, Dubuquoy C, Maggiotto F, Chevalier J, Berrebi D, Dubuquoy L, Boulanger E, et al. 2014 Glugacon-like peptide-2: broad receptor expression, limited therapeutic effect on intestinal inflammation and novel role in liver regeneration. American Journal of Physiology: Gastrointestinal and Liver Physiology 307 G274-G285. (doi:10.1152/ajpgi.00389.2012)

Ellingsgaard H, Ehses JA, Hammar EB, Van Lommel L, Quintens R, Martens G, Kerr-Conte J, Pattou F, Berney T, Pipeleers D, et al. 2008 Interleukin-6 regulates pancreatic alphacell mass expansion. PNAS 105 13163-13168. (doi:10.1073/ pnas.0801059105)

Fraulob JC, Ogg-Diamantino R, Fernandes-Santos C, Aguila MB \& Mandarim-de-Lacerda CA 2010 A mouse model of metabolic syndrome: insulin resistance, fatty liver and non-alcoholic fatty pancreas disease (NAFPD) in C57BL/6 mice fed a high fat diet. Journal of Clinical Biochemistry and Nutrition 46 212-223. (doi:10.3164/jcbn.09-83)

Fujita Y, Wideman RD, Asadi A, Yang GK, Baker R, Webber T, Zhang T, Wang R, Ao Z, Warnock GL, et al. 2010 Glucose-dependent insulinotropic polypeptide is expressed in pancreatic islet alpha-cells and promotes insulin secretion. Gastroenterology 138 1966-1975. (doi:10.1053/j.gastro.2010.01.049)

Geloneze B, Lima MM, Pareja JC, Barreto MR \& Magro DO 2013 Association of insulin resistance and GLP-2 secretion in obesity: a pilot study. Arquivos Brasileiros de Endocrinologia \& Metabologia 57 632-635. (doi:10.1590/S0004-27302013000800008)

Gjesing AP, Vestmar MA, Jørgensen T, Heni M, Holst JJ, Witte DR, Hansen T \& Pedersen O 2011 The effect of PCSK1 variants on waist, waist-hip ratio and glucose metabolism is modified by sex and glucose tolerance status. PLOS ONE 6 e23907. (doi:10.1371/journal. pone.0023907)

Guan X 2014 The CNS glucagon-like peptide-2 receptor in the control of energy balance and glucose homeostasis. American Journal of Physiology: Regulatory, Integrative and Comparative Physiology $\mathbf{3 0 7}$ R585-R596. (doi:10.1152/ajpregu.00096.2014)

Guan X, Karpen HE, Stephens J, Bukowski JT, Niu S, Zhang G, Stoll B, Finegold M, Holst JJ, Hadsell DL, et al. 2006 GLP-2 receptor localizes to enteric neurons and endocrine cells expressing vasoactive peptides and mediates increased blood flow. Gastroenterology 130 150-164. (doi:10.1053/j.gastro.2005.11.005)

Guan X, Shi X, Li X, Chang B, Wang Y, Li DP \& Chan L 2012 GLP-2 receptor in POMC neurons suppresses feeding behavior and gastric motility. American Journal of Physiology: Endocrinology and Metabolism 303 E853-E864. (doi:10.1152/ajpendo.00245.2012)

Hadjiyanni I, Li KK \& Drucker DJ 2009 Glucagon-like peptide-2 reduces intestinal permeability but does not modify the onset of type 1 diabetes in the nonobese diabetic mouse. Endocrinology 150 592-599. (doi:10.1210/en.2008-1228) 
Hameed I, Masoodi SR, Mir SA, Nabi M, Ghazanfar K \& Ganai BA 2015 Type 2 diabetes mellitus: From a metabolic disorder to an inflammatory condition. World Journal of Diabetes 6 598-612. (doi:10.4239/wjd.v6.i4.598)

Hartmann B, Harr MB, Jeppesen PB, Wojdemann M, Deacon CF, Mortensen PB \& Holst JJ 2000 In vivo and in vitro degradation of glucagon like peptide-2 in humans. Journal of Clinical Endocrinology \& Metabolism 85 2884-2888. (doi:10.1210/jcem.85.8.6717)

Hein GJ, Baker C, Hsieh J, Farr S \& Adeli K 2013 GLP-1 and GLP-2 as yin and yang of intestinal lipoprotein production: evidence for predominance of GLP-2-stimulated postprandial lipemia in normal and insulin-resistant states. Diabetes 62 373-381. (doi:10.2337/db12-0202)

Hotamisligil GS 2006 Inflammation and metabolic disorders. Nature 444 860-867. (doi:10.1038/nature05485)

Hsieh J, Longuet C, Maida A, Bahrami J, Xu E, Baker CL, Brubaker PL, Drucker DJ \& Adeli K 2009 Glucagon-like peptide-2 increases intestinal lipid absorption and chylomicron production via CD36. Gastroenterology 137 997-1005. (doi:10.1053/j.gastro.2009.05.051)

Iakoubov R, Lauffer LM, Trivedi S, Kim YI \& Brubaker PL 2009 Carcinogenic effects of exogenous and endogenous glucagonlike peptide-2 in azoxymethane-treated mice. Endocrinology 150 4033-4043. (doi:10.1210/en.2009-0295)

Janssen P, Vanden Berghe P, Verschueren S, Lehmann A, Depoortere I \& Tack J 2011 The role of gastric motility in the control of food intake. Alimentary Pharmacology \& Therapeutics 33 880-894. (doi:10.1111/ j.1365-2036.2011.04609.x)

Janssen P, Rotondo A, Mulè F \& Tack J 2013 Review article: a comparison of glucagon-like peptides 1 and 2. Alimentary Pharmacology \& Therapeutics 37 18-36. (doi:10.1111/apt.12092)

Kappe C, Zhang Q, Nyström T \& Sjöholm A 2014 Effects of high-fat diet and the anti-diabetic drug metformin on circulating GLP-1 and the relative number of intestinal L-cells. Diabetology \& Metabolic Syndrome 6 70. (doi:10.1186/1758-5996-6-70)

Knop FK, Vilsbøll T, Madsbad S, Holst JJ \& Krarup T 2007 Inappropriate suppression of glucagon during OGTT but not during isoglycaemic i.v. glucose infusion contributes to the reduced incretin effect in type 2 diabetes mellitus. Diabetologia 50 797-805. (doi:10.1007/s00125006-0566-Z)

Koopmann MC, Nelson DW, Murali SG, Liu X, Brownfield MS, Holst JJ \& Ney DM 2008 Exogenous glucagon-like peptide-2 (GLP-2) augments GLP-2 receptor mRNA and maintains proglucagon mRNA levels in resected rats. Journal of Parenteral and Enteral Nutrition 32 254-265. (doi:10.1177/0148607108316198)

le Roux CW, Borg C, Wallis K, Vincent RP, Bueter M, Goodlad R, Ghatei MA, Patel A, Bloom SR \& Aylwin SJ 2010 Gut hypertrophy after gastric bypass is associated with increased glucagon-like peptide 2 and intestinal crypt cell proliferation. Annals of Surgery 252 50-56. (doi:10.1097/SLA.0b013e3181d3d21f)

Lee SK, Opara EC, Surwit RS, Feinglos MN \& Akwari OE 1995 Defective glucose-stimulated insulin release from perifused islets of C57BL/6J mice. Pancreas 11 206-211. (doi:10.1097/00006676-199508000-00016)

Lim GE \& Brubaker PL 2006 Glucagon-like peptide 1 secretion by the L cell. Diabetes 55 S70-S77.

Lovshin J, Estall J, Yusta B, Brown TJ \& Drucker J 2001 Glucagon-like peptide (GLP)-2 action in the murine central nervous system is enhanced by elimination of GLP-1 receptor signaling. Journal of Biological Chemistry 276 21489-21499. (doi:10.1074/jbc.M009382200)

Lovshin JA, Huang Q, Seaberg R, Brubaker PL \& Drucker DJ 2004 Extrahypothalamic expression of the glucagon-like peptide-2 receptor is coupled to reduction of glutamate-induced cell death in cultured hippocampal cells. Endocrinology 145 3495-3506. (doi:10.1210/ en.2004-0100)

Lund A, Vilsboll T, Bagger JI, Holst JJ \& Knop FK 2011 The separate and combined impact of the intestinal secretion in type 2 diabetes hormones, GIP, GLP-1, and GLP-2, on glucagon secretion in type 2 diabetes. American Journal of Physiology: Endocrinology and Metabolism 300 E1038-E1046. (doi:10.1152/ajpendo.00665.2010)

Marchetti P, Lupi R, Bugliani M, Kirkpatrick CL, Sebastiani G, Grieco FA, Del Guerra S, D'Aleo V, Piro S, Marselli L, et al. 2012 A local glucagonlike peptide 1 (GLP-1) system in human pancreatic islets. Diabetologia 55 3262-3272. (doi:10.1007/s00125-012-2716-9)

McArdle MA, Finucane OM, Connaughton RM, McMorrow AM \& Roche HM 2013 Mechanisms of obesity-induced inflammation and insulin resistance: insights into the emerging role of nutritional strategies. Frontiers in Endocrinology 4 52. (doi:10.3389/ fendo.2013.00052)

McDonagh SC, Lee J, Izzo A \& Brubaker PL 2007 Role of glial cell-line derived neurotropic factor family receptor a2 in the actions of the glucagon-like peptides on the murine intestine. American Journal of Physiology: Gastrointestinal and Liver Physiology 293 G461-G468. (doi:10.1152/ajpgi.00424.2006)

Meier JJ, Nauck MA, Pott A, Heinze K, Goetze O, Bulut K, Schmidt WE Gallwitz B \& Holst JJ 2006 Glucagon-like peptide 2 stimulates glucagon secretion, enhances lipid absorption, and inhibits gastric acid secretion in humans. Gastroenterology 130 44-54. (doi:10.1053/j. gastro.2005.10.004)

Mingrone G, Panunzi S, De Gaetano A, Guidone C, Iaconelli A, Leccesi L, Nanni G, Pomp A, Castagneto M, Ghirlanda G, et al. 2012 Bariatric surgery versus conventional medical therapy for type 2 diabetes. New England Journal of Medicine 366 1577-1585. (doi:10.1056/ NEJMoa1200111)

Moffett RC, Vasu S, Thorens B, Drucker DJ \& Flatt PR 2014 Incretin receptor null mice reveal key role of GLP-1 but not GIP in pancreatic beta cell adaptation to pregnancy. PLOS ONE 9 e96863. (doi:10.1371/ journal.pone.0096863)

Moore BA, Peffer N, Pirone A, Bassiri A, Sague S, Palmer JM, Johnson DL, Nesspor T, Kliwinski C \& Hornby PJ 2010 GLP-2 receptor agonism ameliorates inflammation and gastrointestinal stasis in murine postoperative ileus. Journal of Pharmacology and Experimental Therapeutics 333 574-583. (doi:10.1124/jpet.109.161497)

Moran GW, O’Neill C \& McLaughlin JT 2012 GLP-2 enhances barrie formation and attenuates TNFa-induced changes in a Caco- 2 cell model of the intestinal barrier. Regulatory Peptides 178 95-101. (doi:10.1016/j.regpep.2012.07.002)

Nelson DW, Sharp JW, Brownfield MS, Raybould HE \& Ney DM 2007 Localization and activation of GLP-2 receptors on vagal afferents in the rat. Endocrinology 148 1954-1962. (doi:10.1210/en.2006-1232)

Nelson DW, Murali SG, Liu X, Koopmann MC, Holst JJ \& Ney DM 2008 Insulin-like growth factor I and glucagon-like peptide- 2 responses to fasting followed by controlled or ad libitum refeeding in rats. American Journal of Physiology: Regulatory, Integrative and Comparative Physiology 294 R1175-R1184. (doi:10.1152/ajpregu.00238.2007)

Nuzzo D, Picone P, Baldassano S, Caruana L, Messina E, Marino Gammazza A, Cappello F, Mulè F \& Di Carlo M 2015 Insulin resistance as common molecular denominator linking obesity to Alzheimer's disease. Current Alzheimer Research 12 723-735. (doi:10.2174/1567205012666150710115506)

Ørskov C, Holst JJ \& Nielsen OV 1988 Effect of truncated glucagon-like peptide-1 [proglucagon-(78-107) amide] on endocrine secretion from pig pancreas, antrum, and nonantral stomach. Endocrinology $\mathbf{1 2 3}$ 2009-2013. (doi:10.1210/endo-123-4-2009)

Ørskov C, Hartmann B, Poulsen SS, Thulesen J, Hare KJ \& Holst JJ 2005 GLP-2 stimulates colonic growth via KGF, released by subepithelial myofibroblasts with GLP-2 receptors. Regulatory Peptides 124 105-112. (doi:10.1016/j.regpep.2004.07.009)

Petersen YM, Elnif J, Schmidt M \& Sangild PT 2002 Glucagon-like peptide 2 enhances maltase-glucoamylase and sucrase-isomaltase gene expression and activity in parenterally fed premature neonatal piglets. Pediatric Research 52 498-503. (doi:10.1203/00006450200210000-00007) http://joe.endocrinology-journals.org

DOI: 10.1530/JOE-16-0035
(C) 2016 Society for Endocrinology Printed in Great Britain
Published by Bioscientifica Ltd. 
Ramsanahie AP, Berger UV, Zinner MJ, Whang EE, Rhoads DB \& Ashley SW 2004 Effect of glucagon-like peptide-2 (GLP-2) on diurnal SGLT1 expression. Digestive Diseases and Sciences 49 1731-1737. (doi:10.1007/s10620-004-9561-8)

Rotondo A, Amato A, Lentini L, Baldassano S \& Mulè F 2011 $a$ Glucagonlike peptide-1 relaxes gastric antrum through nitric oxide in mice. Peptides 32 60-64. (doi:10.1016/j.peptides.2010.09.028)

Rotondo A, Amato A, Baldassano S, Lentini L \& Mulè F $2011 b$ Gastric relaxation induced by glucagon-like peptide- 2 in mice fed a high-fat diet or fasted. Peptides 32 1587-1592. (doi:10.1016/j. peptides.2011.06.031)

Saeidi N, Meoli L, Nestoridi E, Gupta NK, Kvas S, Kucharczyk J, Bonab AA, Fischman AJ, Yarmush ML \& Stylopoulos N 2013 Reprogramming of intestinal glucose metabolism and glycemic control in rats after gastric bypass. Science 341 406-410. (doi:10.1126/ science.1235103)

Sancho V, Trigo MV, Martin-Duce A, Gonz Lez N, Acitores A, Arnés L, Valverde I, Malaisse WJ \& Villanueva-Peñacarrillo ML 2006 Effect of GLP-1 on D-glucose transport, lipolysis and lipogenesis in adipocytes of obese subjects. International Journal of Molecular Medicine 17 1133-1137. (doi:10.3892/ijmm.17.6.1133)

Schauer PR, Kashyap SR, Wolski K, Brethauer SA, Kirwan JP, Pothier CE, Thomas S, Abood B, Nissen SE \& Bhatt DL 2012 Bariatric surgery versus intensive medical therapy in obese patients with diabetes. New England Journal of Medicine 366 1567-1576. (doi:10.1056/ NEJMoa1200225)

Schmidt WE, Siegel EG \& Creutzfeldt W 1985 Glucagon-like peptide-1 but not glucagon-like peptide- 2 stimulates insulin release from isolated rat pancreatic islets. Diabetologia 28 704-707. (doi:10.1007/ BF00291980)

Schmidt PT, Hartmann B, Bregenholt S, Hoist JJ \& Claesson MH 2000 Deficiency of the intestinal growth factor, glucagon-like peptide 2 , in the colon of SCID mice with inflammatory bowel disease induced by transplantation of CD4+ T cells. Scandinavian Journal of Gastroenterology 35 522-527.

Shan CY, Yang JH, Kong Y, Wang XY, Zheng MY, Xu YG, Wang Y, Ren HZ, Chang BC \& Chen LM 2013 Alteration of the intestinal barrier and GLP2 secretion in Berberine-treated type 2 diabetic rats. Journal of Endocrinology 218 255-262. (doi:10.1530/JOE-13-0184)

Shi X, Zhou F, Li X, Chang B, Li D, Wang Y, Tong Q, Xu Y, Fukuda M, Zhao JJ, et al. 2013 Central GLP-2 enhances hepatic insulin sensitivity via activating PI3K signaling in POMC neurons. Cell Metabolism 18 86-98. (doi:10.1016/j.cmet.2013.06.014)

Shin ED, Estall JL, Izzo A, Drucker DJ \& Brubaker PL 2005 Mucosal adaptation to enteral nutrients is dependent on the physiologic actions of glucagon-like peptide-2 in mice. Gastroenterology $\mathbf{1 2 8}$ 1340-1353. (doi:10.1053/j.gastro.2005.02.033)

Sørensen LB, Flint A, Raben A, Hartmann B, Holst JJ \& Astrup A 2003 No effect of physiological concentrations of glucagon-like peptide- 2 on appetite and energy intake in normal weight subjects. International Journal of Obesity and Related Metabolic Disorders 27 450-456. (doi:10.1038/sj.ijo.0802247)

Stephens J, Stoll B, Cottrell J, Chang X, Helmrath M \& Burrin DG 2006 Glucagon-like peptide-2 acutely increases proximal small intestinal blood flow in TPN-fed neonatal piglets. American Journal of Physiology: Regulatory, Integrative and Comparative Physiology 290 R283-R289. (doi:10.1152/ajpgi.00275.2005)

Sueyoshi R, Woods Ignatoski KM, Okawada M, Hartmann B, Holst J \& Teitelbaum DH 2014 Stimulation of intestinal growth and function with DPP4 inhibition in a mouse short bowel syndrome model.
American Journal of Physiology: Gastrointestinal and Liver Physiology $\mathbf{3 0 7}$ G410-G419. (doi:10.1152/ajpgi.00363.2013)

Surwit RS, Kuhn CM, Cochrane C, McCubbin JA \& Feinglos MN 1988 Diet-induced type II diabetes in C57BL/6J mice. Diabetes 37 1163-1167. (doi:10.2337/diab.37.9.1163)

Talior I, Yarkoni M, Bashan N \& Eldar-Finkelman H 2003 Increased glucose uptake promotes oxidative stress and PKC-d activation in adipocytes of obese, insulin-resistant mice. American Journal of Physiology: Endocrinology and Metabolism 285 E295-E302. (doi:10.1152/ajpendo.00044.2003)

Tang-Christensen M, Larsen PJ, Thulesen J, Romer J \& Vrang N 2000 The proglucagon-derived peptide, glucagon-like peptide- 2 , is a neurotransmitter involved in the regulation of food intake. Nature Medicine 6 802-807. (doi:10.1038/77535)

Tavares W, Drucker DJ \& Brubaker PL 2000 Enzymatic- and renaldependent catabolism of the intestinotropic hormone glucagon-like peptide-2 in rats. American Journal of Physiology: Endocrinology and Metabolism 278 E134-E139.

Thulesen J, Hartmann B, Ørskov C, Jeppesen PB, Holst JJ \& Poulsen SS 2000 Potential targets for glucagon-like peptide 2 (GLP-2) in the rat: distribution and binding of i.v. injected ${ }^{125}$ I-GLP-2. Peptides 21 1511-1517. (doi:10.1016/S0196-9781(00)00305-3)

Thulesen J, Knudsen LB, Hartmann B, Hastrup S, Kissow H, Jeppesen PB, Ørskov C, Holst JJ \& Poulsen SS 2002 The truncated metabolite GLP-2 (3-33) interacts with the GLP-2 receptor as a partial agonist. Regulatory Peptides 103 9-15. (doi:10.1016/S0167-0115(01)00316-0)

Tsai CH, Hill M, Asa SL, Brubaker PL \& Drucker DJ 1997 Intestinal growthpromoting properties of glucagon-like peptide-2 in mice. American Journal of Physiology: Endocrinology and Metabolism 273 E77-E84.

Ugleholdt R, Zhu X, Deacon CF, Orskov C, Steiner DF \& Holst JJ 2004 Impaired intestinal proglucagon processing in mice lack in prohormone convertase 1. Endocrinology 145 1349-1355. (doi:10.1210/en.2003-0801)

Valderas JP, Padilla O, Solari S, Escalona M \& González G 2014 Feeding and bone turnover in gastric bypass. Journal of Clinical Endocrinology and Metabolism 99 491-497. (doi:10.1210/jc.2013-1308)

Vrang N, Hansen M, Larsen PJ \& Tang-Christensen M 2007 Characterization of brainstem preproglucagon projections to the paraventricular and dorsomedial hypothalamic nuclei. Brain Research 1149 118-126. (doi:10.1016/j.brainres.2007.02.043)

Weiss R, D’Adamo E, Santoro N, Hershkop K \& Caprio S 2011 Basal alpha-cell up-regulation in obese insulin-resistant adolescents. Journal of Clinical Endocrinology and Metabolism 96 91-97. (doi:10.1210/ jc.2010-1275)

Wideman RD, Covey SD, Webb GC, Drucker DJ \& Kieffer TJ 2007 A switch from prohormone convertase (PC)-2 to PC1/3 expression in transplanted alpha-cells is accompanied by differential processing of proglucagon and improved glucose homeostasis in mice. Diabetes 56 2744-2752. (doi:10.2337/db07-0563)

Wilson-Pérez HE, Chambers AP, Ryan KK, Li B, Sandoval DA, Stoffers D, Drucker DJ, Pérez-Tilve D \& Seeley RJ 2013 Vertical sleeve gastrectomy is effective in two genetic mouse models of glucagon-like peptide-1 receptor deficiency. Diabetes 62 2380-2385. (doi:10.2337/db12-1498)

Wøjdemann M, Wettergren A, Hartmann B \& Holst JJ 1998 Glucagonlike peptide- 2 inhibits centrally induced antral motility in pigs. Scandinavian Journal of Gastroenterology 33 828-832.

Yusta B, Huang L, Munroe D, Wolff G, Fantaske R, Sharma S, Demchyshyn L, Asa SL \& Drucker DJ 2000 Enteroendocrine localization of GLP-2 receptor expression in humans and rodents. Gastroenterology 119 744-755. (doi:10.1053/gast.2000.16489)

Received in final form 21 January 2016

Accepted 24 February 2016

Accepted Preprint published online 3 March 2016 http://joe.endocrinology-journals.org

DOI: $10.1530 / \mathrm{JOE}-16-0035$
(C) 2016 Society for Endocrinology Printed in Great Britain 